\title{
Perancangan Sistem Informasi Akuntansi Upah Lembur Karyawan Menggunakan Extreme Programming
}

\author{
Setiawansyah ${ }^{1}$ \\ Heni Sulistiani ${ }^{2}$ \\ Asri Yuliani ${ }^{3}$ \\ Fikri Hamidy ${ }^{4}$
}

Fakultas Teknik dan Ilmu Komputer, Universitas Teknokrat Indonesia

Jalan ZA. Pagar Alam No.9 -11, Labuhan Ratu, Kec. Kedaton, Kota Bandar Lampung, Indonesia

E-mail:setiawansyah@teknokrat.ac.id ${ }^{1}$;henisulistiani@,teknokrat.ac.id²; fikrihamidy@teknokrat.ac.id ${ }^{3}$; asriyuliani1907@gmail.com ${ }^{4}$

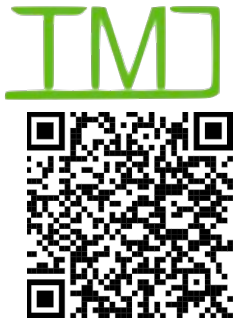

Notifikasi Penulis 30 September 2020

Akhir Revisi

03 November 2020

Terbit

01 Agustus 2021

Setiawansyah, Sulistiani, H., Yuliani, A., \& Hamidy, F. (2021). Perancangan Sistem Informasi Akuntansi Upah Lembur Karyawan Menggunakan Extreme Programming. Technomedia Journal, 6(01 Agustus).

https://doi.org/10.33050/tmj.v6i01 Agustus.1421

\begin{abstract}
ABSTRAK
Bagian produksi PT Sugar Labinta membutuhkan waktu kerja lembur (overtime) untuk menyelesaikan pekerjaannya. Proses kerja lembur ini membutuhkan prosedur dan perhitungan. Salah satu masalah yang sering dihadapi adalah terlalu banyak karyawan yang kerja lembur (overtime) dan terbatasnya sumber daya yang mengelola dan menghitung upah lembur. Bagian staff dalam menghitung upah lembur karyawan harus melihat surat perintah kerja lembur (SPKL) karyawan secara satu persatu sehingga membutuhkan waktu yang lama, lalu menginputkan jam lembur karyawan, gaji pokok, menghitung jam kerja lembur secara manual, serta menghitung pembayaran upah lembur dan total upah lembur, hal ini membutuhkan ketelitian sehingga jika terjadi kesalahan akan merugikan karyawan dan perhitungan upah lembur akan dihitung ulang. Dengan menggunakan metode extreme programming dapat lebih efektif dalam pengerjaan karena dapat menghasilkan aplikasi dengan tingkat efisiensi kinerja yaitu 75\% dari waktu target yang telah direncanakan. Hasil dari sistem informasi akuntansi upah lembur karyawan pada mempermudah pihak perusahaan dalam pembuatan laporan jurnal pengeluaran kas untuk upah lembur karyawan pada PT Sugar Labinta.
\end{abstract}

Kata kunci : Extreme Programming, Sistem Informasi Akuntansi, Upah Lembur.

\section{ABSTRACT}

The production department of PT Sugar Labinta requires overtime to complete its work. This overtime work process requires procedures and calculations. One of the problems that is often faced is too many employees who work overtime and limited resources to manage and calculate overtime pay. The staff section in calculating employee overtime pay must look at the employee overtime work order (SPKL) one by one so that it takes a long time, then input the employee overtime hours, basic salary, calculate overtime hours manually, and calculate overtime pay and total wages overtime, this requires accuracy so that if an error occurs it will harm 
employees and the calculation of overtime pay will be recalculated. Using the extreme programming method can be more effective in the process because it can produce applications with a performance efficiency level of $75 \%$ of the planned target time. The results of the employee overtime wage accounting information system make it easier for the company to make journal reports on cash disbursements for employee overtime wages at PT Sugar Labinta.

Keywords: Extreme Programming, Accounting Information Systems, Overtime Pay.

\section{PENDAHULUAN}

Sistem merupakan serangkain dua atau lebih komponen yang saling terkait dan berinteraksi untuk mencapai tujuan. Sedangkan informasi merupakan data yang telah dikelola dan diproses untuk memberikan arti dan memperbaiki proses pengambilan keputusan [1]. Sebuah organisasi tergantung pada sistem informasi yang baik untuk menjadi daya saing perusahaan, sebagai faktor penting untuk mempertahankan daya saing perusahaan, sistem informasi harus ditingkatkan menjadi lebih baik untuk mempermudah karyawan menyelesaikan pekerjaannya [2]. PT Sugar Labinta adalah sebuah perusahaan yang bergerak dibidang manufacturing. Perusahaan ini memproduksi gula rafinasi sebagai bahan baku pembuatan makanan atau minuman yang didistribusikan kepada industri makanan dan minuman yang terdapat di wilayah Sumatra [3]. Kegiatan operasional membutuhkan kinerja karyawan untuk mencapai target yang maksimal. Bagian produksi membutuhkan waktu kerja lembur (overtime) untuk menyelesaikan pekerjaannya Proses kerja lembur ini membutuhkan prosedur dan perhitungan [4]. Salah satu masalah yang sering dihadapi adalah terlalu banyak karyawan yang kerja lembur (overtime) dan terbatasnya sumber daya yang mengelola dan menghitung upah lembur. Proses perhitungan lembur di perusahaan ini dilakukan oleh HRD (Human Resources Development) menggunakan aplikasi microsoft excel dengan mengambil absen karyawan dari finger print lalu HRD mencocokan lagi karyawan yang lembur dengan waktu lembur yang ada di surat perintah kerja lembur (SPKL) karyawan secara satu persatu sehingga membutuhkan waktu yang lama, lalu menginputkan jam lembur karyawan, gaji pokok, menghitung jam kerja lembur secara manual, serta menghitung pembayaran upah lembur (PUL) dan total upah lembur, hal ini membutuhkan ketelitian sehingga jika terjadi kesalahan akan merugikan karyawan dan perhitungan upah lembur akan dihitung ulang [5]. Perancangan sistem informasi akuntansi upah lembur karyawan menggunakan extreme programming Sebagai peningkatan efisien kinerja karyawan untuk membantu pengambilan keputusan oleh pihak manager serta membantu pihak HRD untuk menghitung upah lembur dan membuat laporan upah lembur karyawan pada PT Sugar Labinta Lampung Selatan [6].

\section{PERMASALAHAN}

Berdasarkan hasil wawancara yang dilakukan proses perhitungan lembur di perusahaan ini dilakukan oleh HRD berdasarkan absensi karyawan lalu HRD mencocokan lagi karyawan yang lembur dengan waktu lembur yang ada di surat perintah kerja lembur (SPKL) karyawan secara satu persatu sehingga membutuhkan waktu yang lama, lalu menginputkan jam lembur karyawan, gaji pokok, menghitung jam kerja lembur secara manual, serta menghitung pembayaran upah lembur dan total upah lembur, hal ini membutuhkan ketelitian sehingga jika terjadi kesalahan akan merugikan karyawan dan perhitungan upah lembur akan dihitung ulang, maka dari itu membutuhkan sebuah sistem informasi akuntansi untuk mengatasi permasalahan yang terjadi [7]. 


\section{METODOLOGI PENELITIAN} diperlukan:

Teknik pengumpulan data yang akan digunakan peneliti dalam pengumpulan data yang

1. Observasi : melakukan observasi dan analisis data yang diperlukan untuk membangun sistem informasi perhitungan upah lembur pada PT Sugar Labinta.

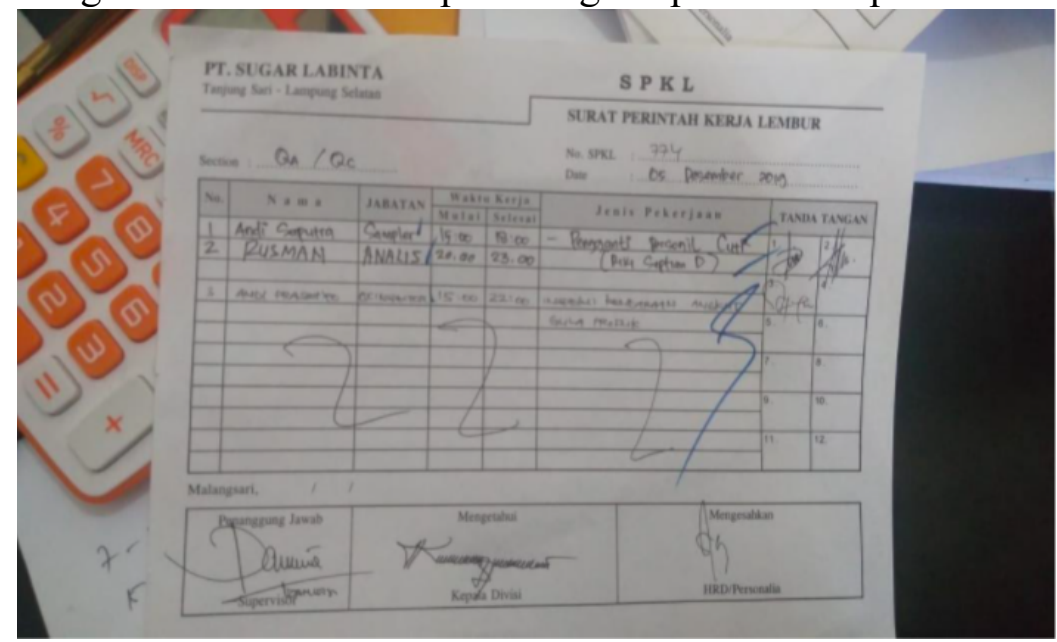

Gambar 1. Berkas Surat Perintah Kerja Lembur (SPKL)

(Sumber : PT Sugar Labinta)

2. Wawancara : melakukan wawancara kepada pihak HRD di PT Sugar Labinta

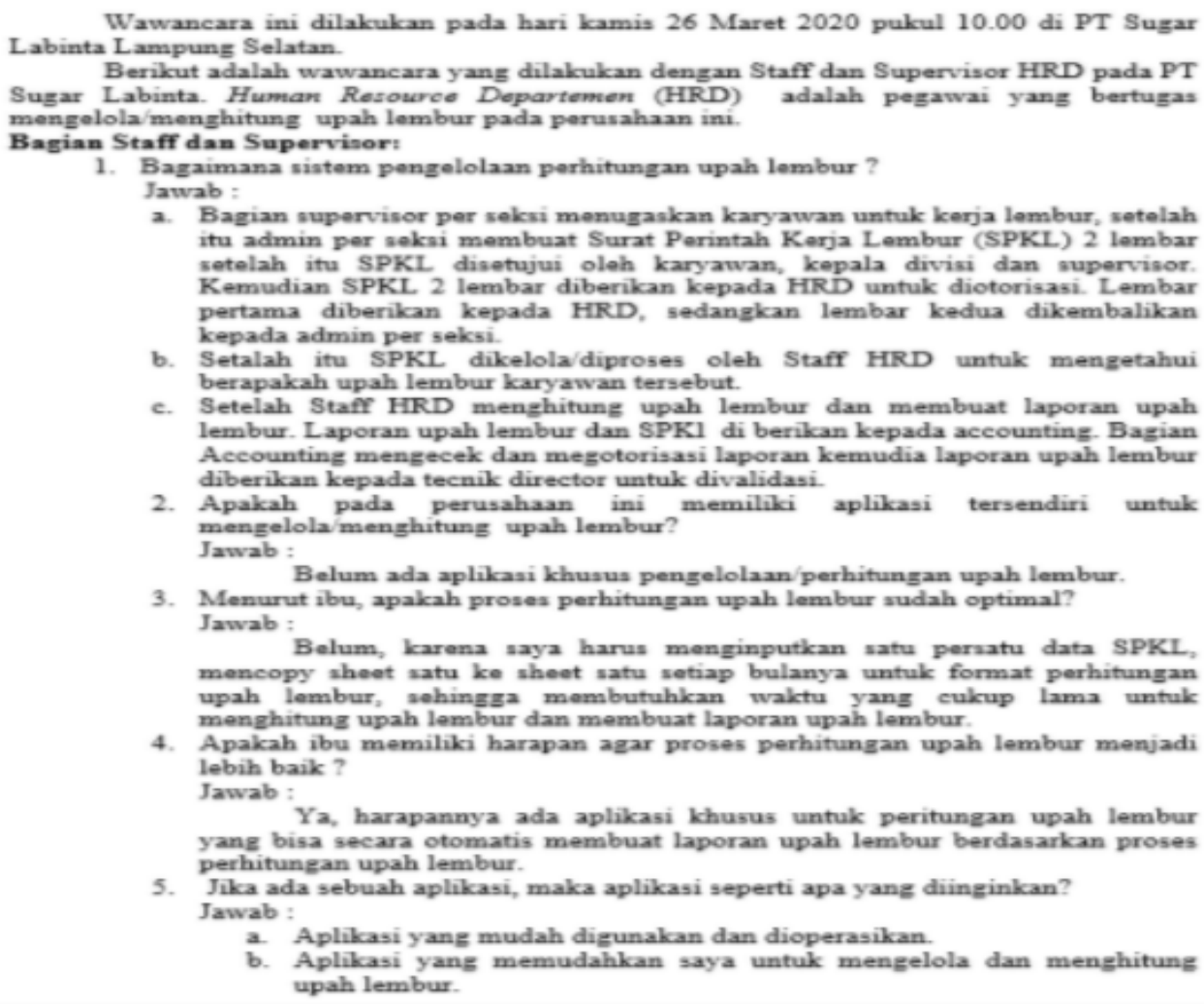

a. Bagian supervisor per selksi menugaskan karyawan untuk kerja lembur, setelah itu admin per seksi membuat Surat Perintah Kerja Lembur (SPKI) 2 lembar setelah itu SPKI disetujui oleh karyawan, kepala divisi dan supervisor. Kemudian SPKI. 2 lembar diberikan kepada HRD untuk diotorisasi. Lembax pertama diberikan kepada HRD, sedangkan lembax kedua dikembalikan kepada admin per seksi.

b. Setalah itu SPKI dikelola/diproses oleh Staff HRD untuk mengetahui berapakah upah lembur karyawan tersebut.

c. Setelah Staff HRD menghitung upah lembur dan membuat laporan upah lembur. Laporan upah lembur dan SPKI di berikan kepada accounting. Bagian Accounting mengecek dan megotorisasi laporan kemudia laporan upah lembur diberikan kepada tecnik director untuk divalidasi.

2. Apakah pada perusahasn ini memiliki aplikasi tersendiri untuk mengelola menghitumg upah lembur? Jawab:

Belum ada aplikasi khusus pengelolaan perhitungan upah lembur. Menurut ibu, apakah proses perhitungan upah lembur sudah optimal? Jawab:

Belum, karena saya harus menginputkan satu peratu data SPKL. mencopy sheet satu ke sheet satu setiap bulanya untuk format perhitungan upah lembur, a hing ma membutuhkan waktu yang cukup lama untuk upah lembur, aehingga mombutuhkan waktu yang cukup las

4. Apakah ibu memiliki harapan agar proses perhitungan upah lembur menjadi lebih baik ? Jawab:

Ya, harapannya ada aplikasi khusus untuk peritungan upah lembur yang bisa secara otomatis membuat laporan upah lembur berdasarkan proses perhitungan upah lembur.

5. Jika ada sebuah aplikasi, maka aplikasi seperti apa yang diinginkan? Javiab:

a. Aplikasi yang mudah digunakan dan dioperasikan.
b. Aplikasi yang memudahkan saya untuk mengelola dan menghitung upah lembur.

Gambar 2. Hasil Wawancara

(Sumber : HRD PT Sugar Labinta) 
3. Metode Pengembangan Perangkat Lunak

Metode ini merupakan metode yang akan digunakan peneliti dalam proses pengembangan perangkat lunak dari penelitian ini. Metode yang akan digunakan adalah metode Extreme Programming [4].

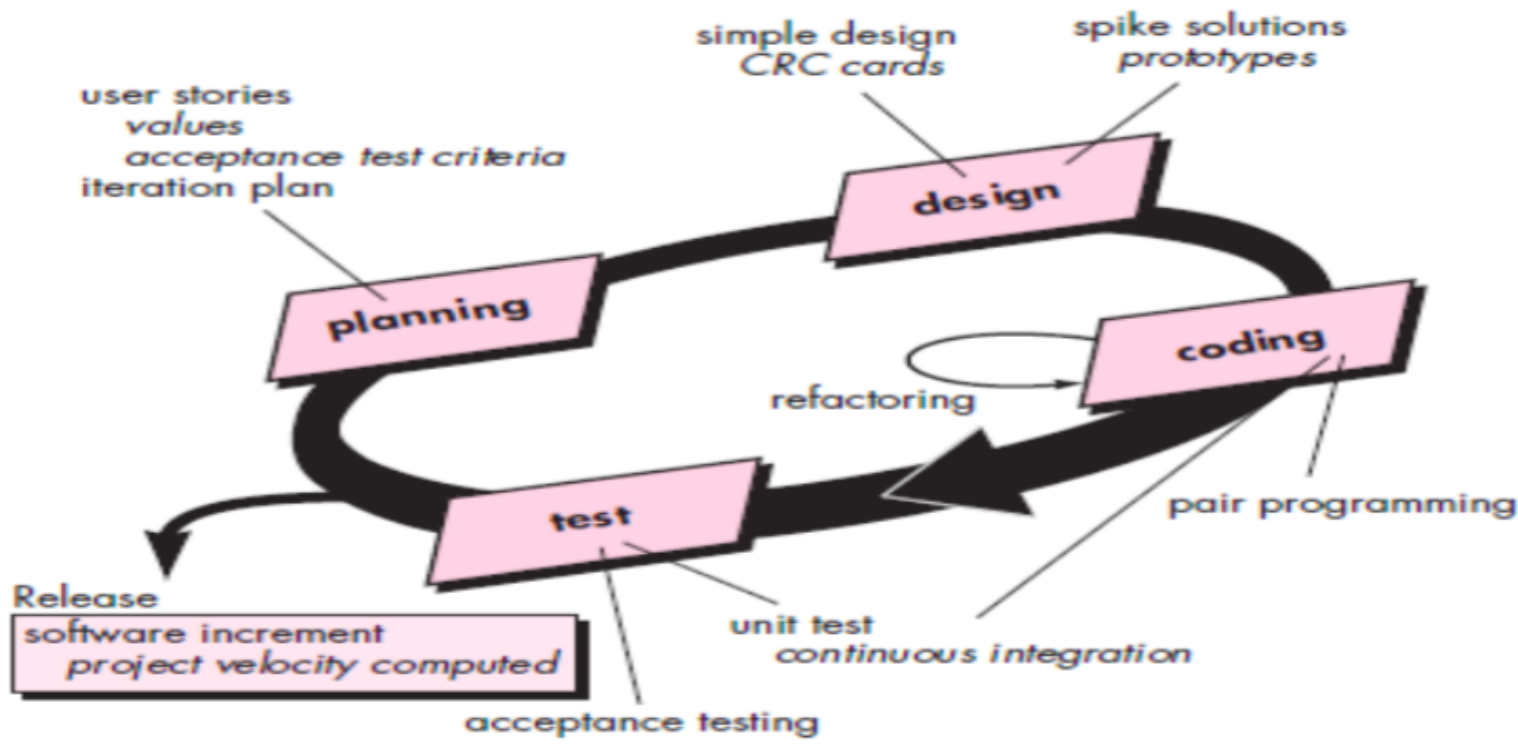

Gambar 3. Metode Extreme Programming

Tahapan dalam metode pengembangan sistem Extreme Programming yaitu :

\section{A. Planning}

Pada tahap perencanaan ini dimulai dari pengumpulan kebutuhan yang membantu tim teknikal untuk memahami konteks bisnis dari sebuah aplikasi [8]. Selain itu pada tahap ini juga mendefinisikan output yang akan dihasilkan, fitur yang dimiliki oleh aplikasi dan fungsi dari aplikasi yang dikembangkan [9]. Dalam tahapan ini menggunakan analisis PIECES yaitu

Tabel 1. Analisis PIECES

\begin{tabular}{|l|l|}
\hline Analisis & Sistem Lama \\
\hline Performance & $\begin{array}{l}\text { Kinerja sistem yang dilakukan secara excel } \\
\text { membutuhkan waktu yang cukup lama untuk proses } \\
\text { perhitungan dan pelaporannya. }\end{array}$ \\
\hline Information & $\begin{array}{l}\text { Penyimpanan data masih menggunakan flashdisk } \\
\text { atau hardisk sehingga banyak data ganda } \\
\text { (redundancy). }\end{array}$ \\
\hline Economy & Biaya upah lembur yang dikeluarkan sudah akurat. \\
\hline Control & $\begin{array}{l}\text { Kurang adanya keamanan data karena data } \\
\text { tersimpan di beberapa tempat. }\end{array}$ \\
\hline
\end{tabular}




\begin{tabular}{|l|l|} 
& $\begin{array}{l}\text { kurang adanya kontrol hasil pekerjaan antara Staff } \\
\text { dan Supervisor HRD }\end{array}$ \\
\hline Efficiency & $\begin{array}{l}\text { Rekapitulasi yang masih dilakukan secara } \\
\text { spreadsheet menyebabkan terjadinya kesalahan } \\
\text { dalam memindahkan data dan memakan waktu } \\
\text { yang cukup lama. }\end{array}$ \\
\hline Service & $\begin{array}{l}\text { Proses pelayanan terhadap perhitungan upah } \\
\text { lembur membutuhkan waktu apabila terjadi } \\
\text { kesalahan hitung. }\end{array}$ \\
\hline
\end{tabular}

\section{B. Design}

Metode ini menekankan desain aplikasi yang sederhana, untuk mendesain aplikasi dapat menggunakan Class-Responsibility-Collaborator (CRC) cards yang mengidentifikasi dan mengatur class pada object-oriented pada aplikasi yang akan dibuat [10].

\section{Coding}

Konsep utama dari tahapan pengkodean pada extreme programming adalah pair programming, melibatkan lebih dari satu orang untuk menyusun kode program untuk aplikasi [11].

\section{Test}

Pada tahapan ini lebih fokus pada pengujian fitur dan fungsionalitas menggunakan blackbox testing dari aplikasi yang dibuat [12].

\section{LITERATURE REVIEW}

Literature review yang digunakan dalam penelitian ini adalah

1. Hasil penelitian yang dilakukan oleh peneliti, efektivitas sistem informasi akuntansi penggajian karyawan di PT Bank Pembiayaan Rakyat Syariah Al Washliyah Medan belum berjalan secara efektif [13]. Hal ini dapat dilihat dari dokumen yang digunakan di perusahaan adalah tidak adanya slip gaji pada daftar gaji [14]. Perusahaan hanya menerapkan gaji amprah yang tercantum pada gaji buku amprah. Tidak adanya gaji membuat karyawan tidak menyadari berapa banyak gaji yang diterima dan berapa banyak potongan yang dibebankan kepada karyawan setiap bulan, sehingga menyulitkan departemen keuangan untuk membuat laporan penggajian dan tidak menerapkan memorial dan laporan pendapatan karyawan sebagai dokumen untuk remunerasi daftar gaji Akuntansi sulit untuk membuat jurnal penggajian [15]. Catatan akuntansi yang digunakan dalam sistem informasi akuntansi penggajian pada PT. Bank Pembiayaan Rakyat Syariah Al Washliyah Medan hanya menggunakan jurnal umum [16]. Dalam melakukan penjurnalan penggajian PT Bank Pembiayaan Rakyat Syariah Al Washliyah Medan belum menerapkan bukti memorial dan kartu penghasilan karyawan sebagai dokumen untuk pencatatan penggajian [17].

2. Hasil penelitian tentang perancangan sistem informasi akuntansi siklus penggajian pada perusahaan retail [18]. Hasil penelitian ini mengidentifikasi. menganalisis serta merancang sebuah sistem informasi akuntansi penggajian untuk mendukung proses penggajian pada perusahaan retail [19], [20]. Metode perancangan yang digunakan adalah metode Object Oriented Analysis and Design (OOAD) yang mengacu pada pemodelan [19]. Untuk menggali informasi mengenai proses bisnis yang berjalan, 
maka dilakukan beberapa tahap seperti survei, wawancara dan identifikasi masalah. Analisis dilakukan berdasarkan proses penggajian yang saat ini berjalan, selanjutnya hasil analisis dituangkan dalam perancangan sistem informasi akuntansi penggajian berupa aplikasi web yang dapat membantu kegiatan absensi, izin/cuti, lembur, pinjaman dan penggajian, khususnya pendokumentasian dan penyimpanan data yang terintegrasi sehingga membantu mempercepat proses perhitungan gaji karyawan.

\section{HASIL DAN PEMBAHASAN}

Perancangan sistem informasi akuntansi upah lembur karyawan menggunakan extreme programming ini dengan menggunakan pendekatan berorientasi objek yaitu menggunakan use case diagram[11]. Use case diagram sistem informasi akuntansi upah lembur karyawan dapat dilihat pada gambar 4 berikut ini

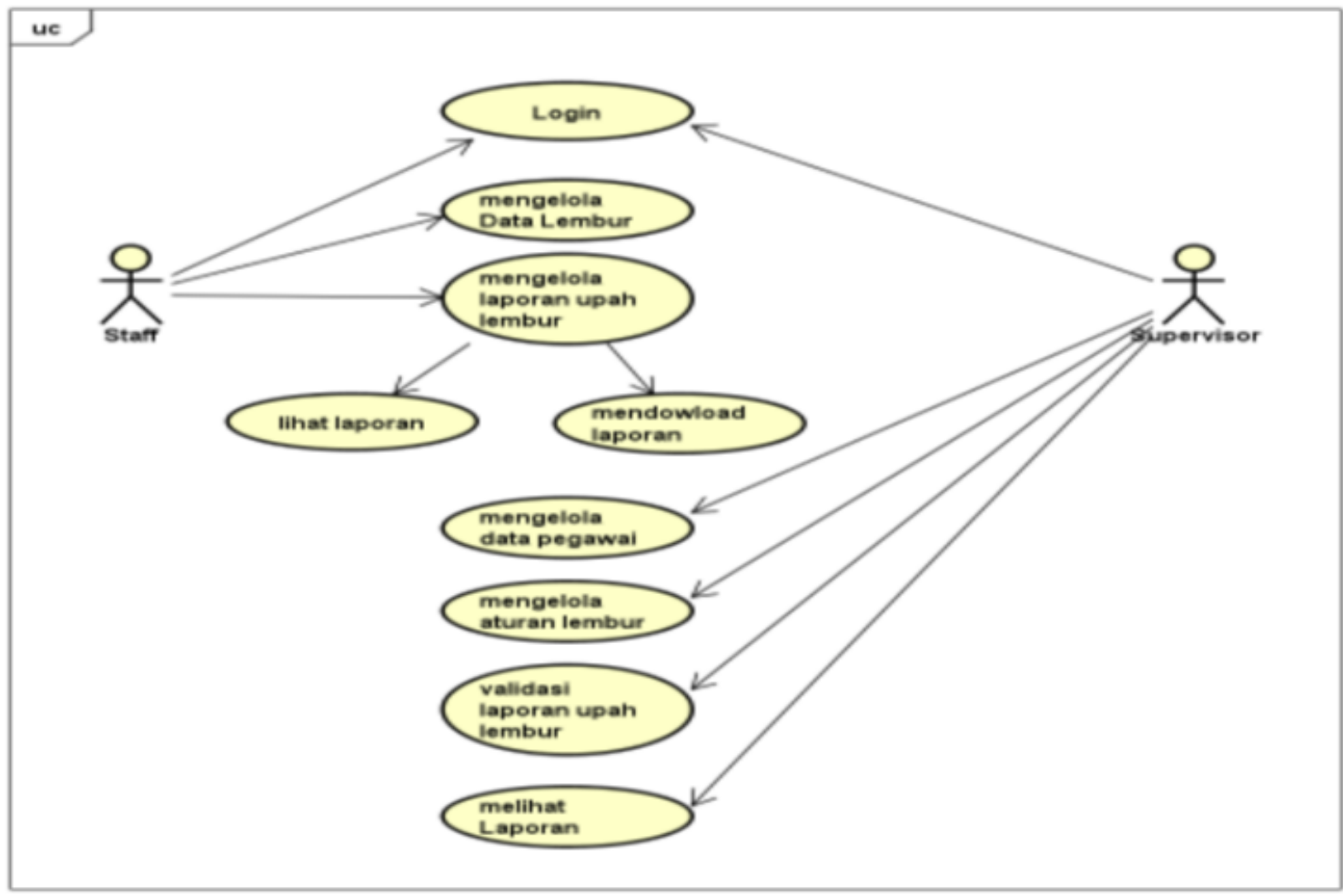

Gambar 4. Use Case Diagram

Staff HRD adalah orang yang bertugas mengelola data upah lembur, dan mengelola laporan upah lembur dalam sistem. Supervisor HRD adalah orang yang bertugas mengawasi kerja staff HRD, maka dari itu tugas supervisor HRD pada sistem yaitu memvalidasi laporan dan melihat laporan serta mengelola data pegawai, mengelola aturan upah lembur.

Konsep pair programming yang digunakan dalam sistem akuntansi upah lembur karyawan menggunakan dengan bahasa pemograman C\# dan Database Firebase. 


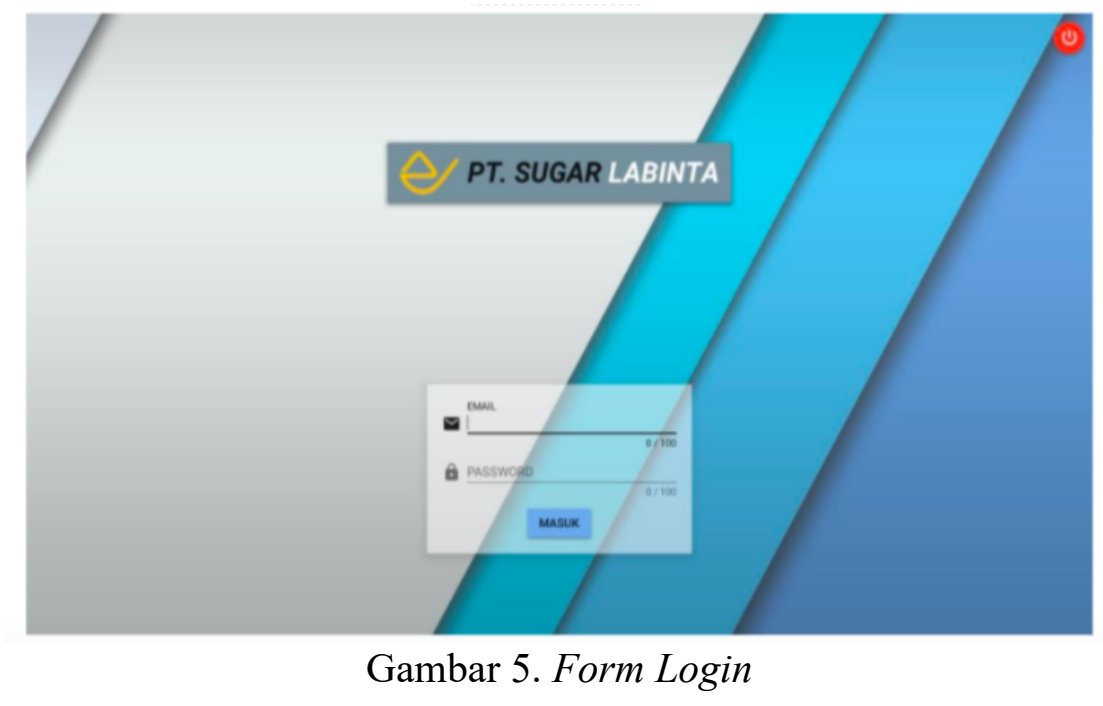

Form login adalah tampilan untuk masuk ke dalam sistem, dengan menginputkan email dan password dengan benar dan sesuai dengan yang telah ditentukan pada saat user.

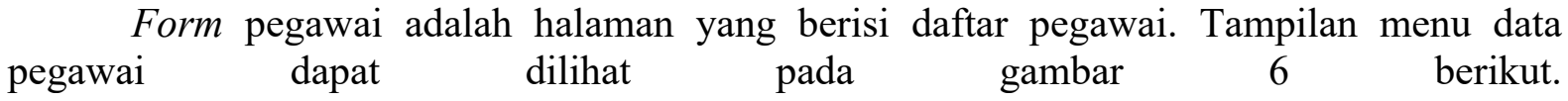

\begin{tabular}{|c|c|c|c|c|c|c|c|c|c|}
\hline \multicolumn{2}{|c|}{ 三 OATA LQMEUR } & \multicolumn{3}{|c|}{ 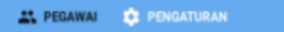 } & \multicolumn{2}{|r|}{$60.15 \mathrm{FPS}$} & \multicolumn{3}{|r|}{ Superitiser $\theta$} \\
\hline c & \pm \pm & & & & - Can Berda & $\operatorname{kan} \max$ & & ${ }+$ muar $30^{\circ}$ & Cs tamplukan senu \\
\hline no & $=x$ & no Mases & nemen & ons & secsis & дентам & $\mathrm{nax}$ & CWipokok & \\
\hline 1 & 120780041537 & э19 & Wowan Kistan & Production & Procoss - MR & MR Filing Rocem Operater 3 & $16 \mathrm{Ju} 2012$ & 190, 3,250,000 & \\
\hline 2 & 1207805051553 & 3227 & AG Seloumen & Production & Process - MR & MR Filing Roem 0perater 3 & 23042012 & \$Q2 40000000 & \\
\hline 3 & 120780021596 & 3 Mat & Has WOSOEO & Production & Process - Me & MR Filing Aloom 0perser 2 & $16 \mathrm{sul} 2012$ & Re:3000000 & \\
\hline 4 & 120790001534 & 304 & Aqus Pront Girsang & Production & Maintemance & Drstiman 3 & $164 k+2012$ & $R_{0,3750,100}$ & \\
\hline 5 & 1207901011220 & $300 \mathrm{H}$ & Angga Kitsobanturo & Poduction & Process - MR & Mr Filing frocm 0perster 3 & O2:-2012012 & M02.500.000 & \\
\hline 6 & 120791091542 & 32004 & Yosepp Aryonto & Production & Process - MR & MR Filing focm Operater 3 & $16 \mathrm{di}+2012$ & Rp 35000000 & \\
\hline 7 & 120092031527 & З13н & Prastono & Production & Procoss - MR & MR Filling Rocen Operater 3 & Q2Nat2012 & Re 3000000 & \\
\hline 8 & 120793051520 & 300 & Asep Wohyo Frimaneyson & Production & Process - Mr & MR Filing Rocm 0perste 2 & Q2ut2012 & R०2,750,000 & \\
\hline 9 & 120093011570 & 364 & Aang Menhodk & Aroduction & Process - Mr & MR Filing from 0perster 3 & 01-Aug 2012 & Ap 2,500,000 & \\
\hline 10 & 12009303157 & 34SH & Gta Avd Wrarate & Production & Process - MR & MR Filling Focm Operater 3 & 01-Aug 2012 & Apa3750,000 & \\
\hline 11 & 120093061593 & 313 & Kumranto & Production & Maintannece & Toal Kaeperer 2 & 09 Aug 2012 & Ap 30000000 & \\
\hline 12 & 120082111604 & 1 $360 \mathrm{H}$ & Hejar Aemadi & Production & Prooss - MR & Me Filing foom Operater 3 & $06 \operatorname{sep} 2012$ & Mp 2.500,1000 & \\
\hline 13 & 121092071616 & 322 & KMisena Yosta Anerike & Production & Maintenence & Toal Kepeper 2 & $01-0 \mathrm{et} 2012$ & Ap 3250,000 & \\
\hline 14 & 1211740221636 & 352 & supianto & Aoduction & Process - MR & Me Filing flocm 0perster 3 & $07+$ Nor 2012 & Ap 2,500,000 & \\
\hline 15 & 121178061625 & 331 & Shentear Mustisa & Production & Produston & Adminatraticn Staft 1 & O1) Nov 2012 & 190,3,250,000 & \\
\hline 16 & 121178071755 & 367 & Hemen Findy & Production & Rocoss : MR & Mer Fing foem Operater 3 & 21) Now 2012 & 1903750,000 & \\
\hline 17 & 1218101001650 & 366 & Desty sunaryo & Production & Process - MR & MR Filing floem Operater 3 & 21 Now 2012 & AQ 15000000 & \\
\hline 18 & 121182051652 & 2. 360 & Supryod & Production & Process - MR & MR Filing Room 0pertor 3 & 21 Noov 2012 & Ap 2,750,000 & \\
\hline 19 & 121180031626 & 332 & Sued & Production & Process - MR & Ma Fing flocm Operster 3 & 07 - $\mathrm{Nov} 2012$ & Ap:3250,000 & \\
\hline 20 & 121180991600 & 356 & Satia Kesuma Sundwan & Syatem adim & Purchasing & Purchosing staff 3 & 01 Now 2012 & RQ $1,300,000$ & \\
\hline 21 & 121189011632 & 238 & Fallyante & Production & Rocess : MR & Me Filing foom Dperater 3 & O1 Now 2012 & Ap 30000000 & \\
\hline 22 & 1211960121653 & 360 & Destiumen & Production & Procoss-MR & Me filing focem Operater 3 & $23+60+2012$ & Re.3750,000 & \\
\hline
\end{tabular}

Gambar 6. Form Data Pegawai

Form pegawai digunakan untuk mengelola data pegawai dapat berupa tambah data pegawai, hapus data pegawai, edit data pegawai, dan pencarian data pegawai. Menu ini dikelola oleh supervisor. 


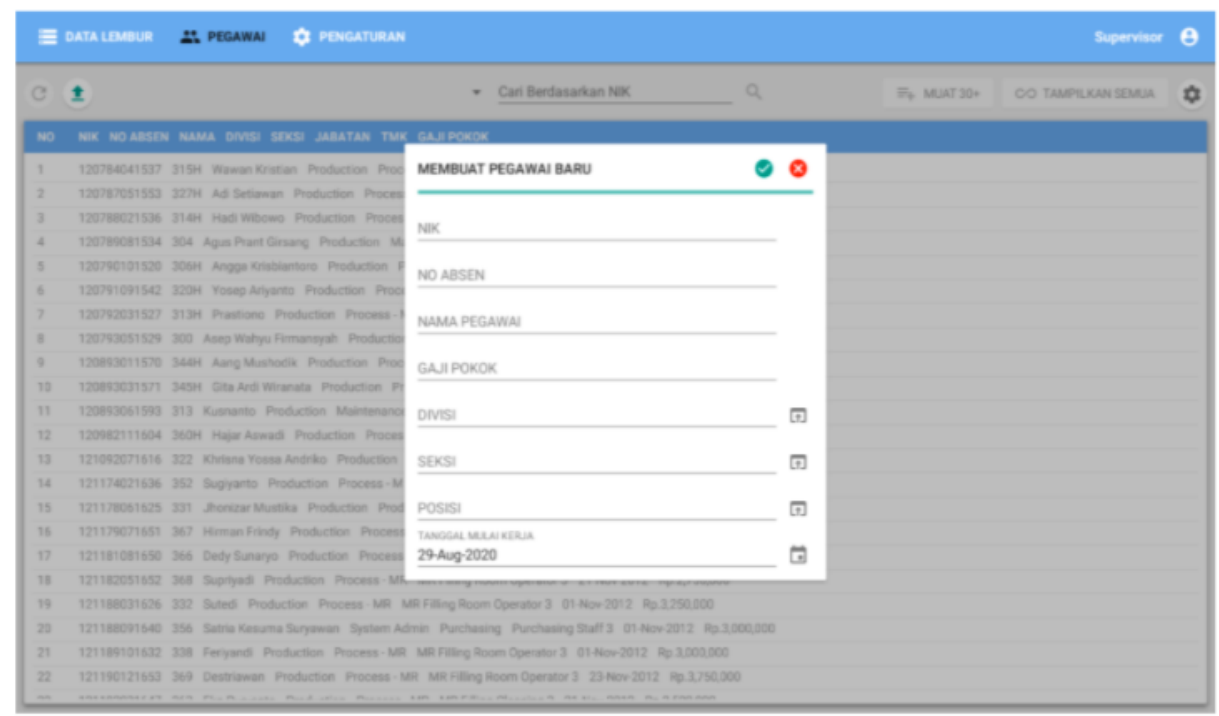

Gambar 7. Form Input Data Pegawai

Form input data pegawai digunakan untuk memasukan data pegawai baru yang berisi NIK, Nomor absen, nama pegawai, gaji pokok, divisi, seksi, posisi, dan tanggal masuk kerja.

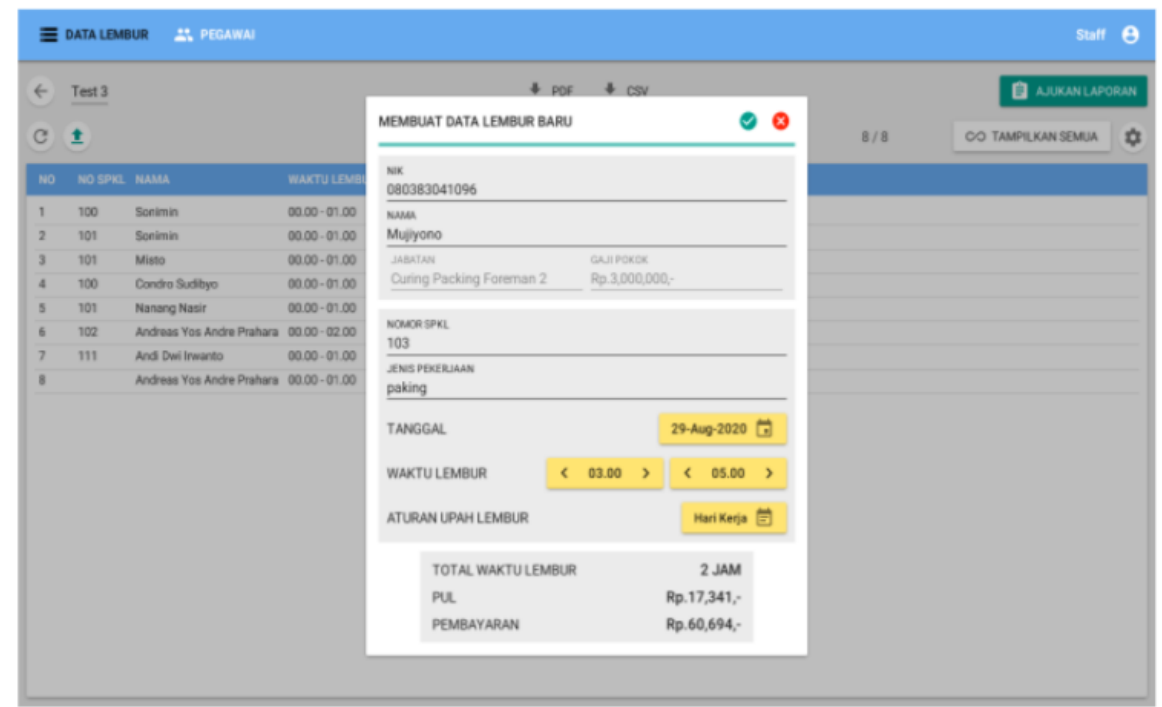

Gambar 8. Form Input Data Lembur Pegawai

Form entry data lembur baru staff menginputkan NIK, nama pegawai, jabatan, gaji pokok, nomor SPKL, pekerjaan, tanggal lembur, waktu lembur, aturan upah lembur. 


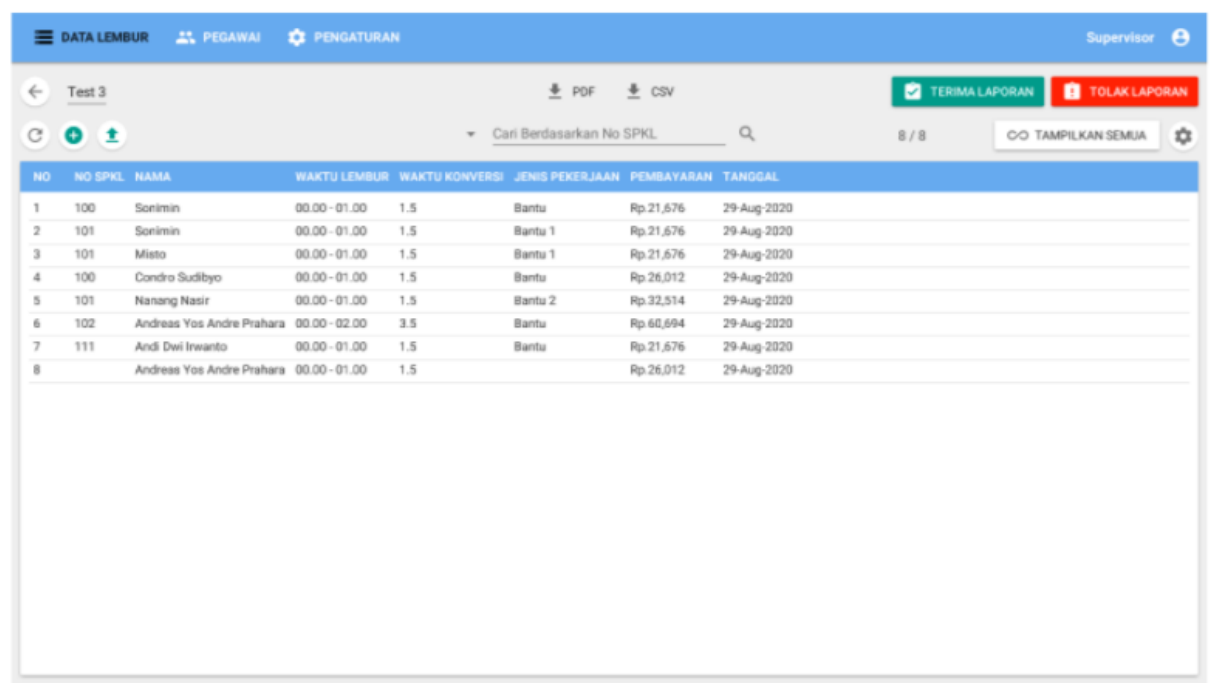

Gambar 9. Form Validasi Data Lembur Pegawai

Data validasi merupakan validasi data upah lembur yang sudah dibuat dan diajukan oleh staff dan harus divalidasi oleh supervisor.

\begin{tabular}{|c|c|c|c|c|c|c|}
\hline \multicolumn{4}{|c|}{$\ominus \mid$ SUGAR } & \multicolumn{3}{|c|}{$\begin{array}{r}\text { LAPORAN UPAH LEMBUR } \\
\text { Aug } 2020\end{array}$} \\
\hline No & Tanggal & No SPKL & Nama Pegawal & Jenis Pekerjaan & $\begin{array}{c}\text { Waktu Lembur } \\
\text { Konversi }\end{array}$ & Pembayaran \\
\hline 1 & 02-Aug-2020 & 102 & $\begin{array}{l}\text { Acen Mergiyanjaya } \\
090490081403\end{array}$ & target produksi & 4 & Rp. 69,364 \\
\hline 2 & 02-Aug-2020 & 102 & $\begin{array}{l}\text { Ngationo } \\
131194011708\end{array}$ & paking gula & 4 & Rp.63.584 \\
\hline 3 & 03-Aug-2020 & 103 & $\begin{array}{l}\text { Dimas Prayogo } \\
140391041716 \\
\end{array}$ & memeproduksi target gula & 5.5 & Rp.95,376 \\
\hline 4 & 11-Aug-2020 & 104 & $\begin{array}{l}\text { Agus Riyanto } \\
140968071725\end{array}$ & menyaring raw sugar & 5.5 & Rp. 103,324 \\
\hline 5 & 11-Aug-2020 & 104 & $\begin{array}{l}\text { Heri Faiar Iswadi } \\
110386091470\end{array}$ & menyaring raw sugar & 3.5 & Rp. 80,925 \\
\hline 6 & 11-Aug-2020 & 104 & $\begin{array}{l}\text { Prastiono } \\
120792031527\end{array}$ & paking gula & 5.5 & Rp.95,376 \\
\hline 7 & 26-Aug-2020 & 105 & $\begin{array}{l}\text { Suharni } \\
101281112451 \\
\end{array}$ & \begin{tabular}{|l|} 
membantu memasak untuk orang \\
lembur
\end{tabular} & 1.5 & Rp. 23,844 \\
\hline 8 & 27-Aug-2020 & 105 & $\begin{array}{l}\text { Saras Want } \\
101282072452 \\
\end{array}$ & belanja ke pasar & 5.5 & Rp.95.376 \\
\hline 9 & 30-Aug-2020 & 101 & $\begin{array}{l}\text { Andi Saputra } \\
130692051692 \\
\end{array}$ & mengambil sempel produk baru & 6 & Rp.86,705 \\
\hline 10 & 30-Aug-2020 & 101 & $\begin{array}{l}\text { Rusman } \\
120783011549\end{array}$ & analisis produk & 6 & Rp. 86,705 \\
\hline \multicolumn{6}{|c|}{ Total Pembayaran } & Rp. 800,579 \\
\hline \multicolumn{4}{|c|}{ disetujui } & \multicolumn{3}{|c|}{$\begin{array}{l}\text { Lampung Selatan, } \\
\text { dibuat oleh }\end{array}$} \\
\hline
\end{tabular}

Gambar 10. Form Laporan Data Lembur Pegawai

Laporan upah lembur terdapat tanggal lembur, No.SPKL, nama pegawai, Jenis pekerjaan, waktu kerja, dan jumlah pembayaran upah lembur. 
Hasil Kesepakatan Perjanjian Kerja Bersama (PKB), PT Sugar Labinta menggunakan tata cara perhitungan pembayaran upah lembur (PUL) adalah sebagai berikut.

Tabel 1. Perhitungan Upah Lembur

\begin{tabular}{|l|l|l|l|}
\hline No. & Cara Pembayaran & Hari Kerja Biasa & Hari Kerja Libur \\
\hline 1. & Bulanan & Jam ke 1: & Jam ke 1-7: \\
& $1 / 173$ X Gaji Pokok & 1,5 X PUL & 2 X PUL \\
& /bulan & Jam ke 2-7: & Jam ke 8 : \\
& & 2 X PUL & 3 X PUL \\
& & Jam ke 9: \\
& & & 4 X PUL. \\
\hline
\end{tabular}

Adapun cara menghitung pembayaran upah lembur adalah sebagai berikut:

1. Menghitung berapa jam karyawan dengan nama Dimas Prayogo tersebut bekerja, Karyawan tersebut kerja lembur selama 3 jam.

2. Menghitung upah lembur:

Jam 1 dikali dengan 1,5 PUL $=1,5$

Jam 2 dikali dengan 2 PUL $=4$

Jadi lembur 3 jam $=5,5$ upah lembur

10. Menghitung cara pembayaran upah lembur dengan rumus $1 / 173 \mathrm{X}$ gaji pokok

$1 / 173$ X $3.000 .000=$ Rp. 14.451 per satu jam

5,5 X Rp. $14.451=$ Rp. Rp 95.376

Jadi pembayaran upah lembur 3 jam lembur adalah sebesar Rp. 95.376

\begin{tabular}{|c|c|c|c|c|c|c|}
\hline e/sugar & & & & \multicolumn{3}{|c|}{$\begin{array}{r}\text { Jumal Pengeluaran Kas } \\
\text { Agustus } 2020\end{array}$} \\
\hline Tanggal & Kode Akun & Nama Akun & \multirow{2}{*}{\begin{tabular}{|r|r|} 
Ref \\
SPKL 102 \\
\end{tabular}} & Debet & \multicolumn{2}{|c|}{ Kredit } \\
\hline $02 / 08 / 2020$ & 1101 & Kas & & Rp $\quad 69.364$ & $\mathrm{Rp}$ & - \\
\hline $02 / 08 / 2020$ & 5102 & Beban Gaji Lembur & SPKL 102 & $\mathrm{Rp}$ & $\mathrm{Rp}$ & 69.364 \\
\hline $02 / 08 / 2020$ & 1101 & Kas & SPKL 102 & 63.584 & $\mathrm{Rp}$ & - \\
\hline $02 / 08 / 2020$ & 5102 & Beban Gaji Lembur & SPKL 102 & $R p$ & $R p$ & 63.584 \\
\hline $03 / 08 / 2020$ & 1101 & Kas & SPKL 103 & 95.376 & $\mathrm{Rp}$ & - \\
\hline $03 / 08 / 2020$ & 5102 & Beban Gaji Lembur & SPKL 103 & $\mathrm{Rp}$ & $\mathrm{Rp}$ & 95.376 \\
\hline $11 / 08 / 2020$ & 1101 & Kas & SPKL 104 & 103.324 & $\mathrm{Rp}$ & \\
\hline $11 / 08 / 2020$ & 5102 & Beban Gaji Lembur & SPKL 104 & & $R p$ & 103.324 \\
\hline $11 / 08 / 2020$ & 1101 & Kas & SPKL 104 & 80.925 & Rp & \\
\hline $11 / 08 / 2020$ & 5102 & Beban Gaji Lembur & SPKL 104 & $\mathrm{Rp}$ & $\mathrm{Rp}$ & 80.925 \\
\hline $11 / 08 / 2020$ & 1101 & Kas & SPKL 104 & 95.376 & $\mathrm{Rp}$ & \\
\hline $11 / 08 / 2020$ & 5102 & Beban Gaji Lembur & SPKL 104 & $\mathrm{Rp}$ & $\mathrm{Rp}$ & 95.376 \\
\hline $26 / 08 / 2020$ & 1101 & 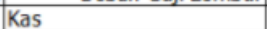 & SPKL 104 & 23.844 & $\mathrm{Rp}$ & - \\
\hline $26 / 08 / 2020$ & 5102 & Beban Gaji Lembur & SPKL 104 & $R p$ & Rp & 23.844 \\
\hline $27 / 08 / 2020$ & 1101 & Kas & SPKL 105 & 95.376 & $\mathrm{Rp}$ & \\
\hline $27 / 08 / 2020$ & 5102 & Beban Gaji Lembur & SPKL 105 & $\mathrm{Rp}$ & $\mathrm{Rp}$ & 95.376 \\
\hline $30 / 08 / 2020$ & 1101 & Kas & SPKL 105 & 86.705 & $\mathrm{Rp}$ & - \\
\hline $30 / 08 / 2020$ & 5102 & Beban Gaji Lembur & SPKL 105 & $R p$ & $R p$ & 86.705 \\
\hline $30 / 08 / 2020$ & 1101 & Kas & SPKL 101 & 86.705 & Rp & \\
\hline $30 / 08 / 2020$ & 5102 & Beban Gaji Lembur & SPKL 101 & $\mathrm{Rp}$ & $\mathrm{Rp}$ & 86.705 \\
\hline \multicolumn{4}{|c|}{ Total Saldo Pengeluaran Kas } & 800.579 & Rp & 800.579 \\
\hline
\end{tabular}

Gambar 11. Form Laporan Jurnal Pengeluaran Kas

Laporan jurnal pengeluaran kas berisi informasi tentang tanggal, kode akun, nama akun, ref, debet dan kredit. Laporan jurnal pengeluaran kas sebagai informasi akuntansi tentang pengeluaran kas yang ada pada PT Sugar Labinta.

Hasil pengujian black box testing dari 5 komponen pengujian yang sudah dilakukan maka didapatkan hasil yaitu 
Tabel 2. Hasil Pengujian Blackbox Testing

\begin{tabular}{|c|c|c|}
\hline \multirow[b]{2}{*}{ Kriteria Pengujian } & \multicolumn{2}{|c|}{ Jumlah Jawaban } \\
\hline & Sesuai & Tidak Sesuai \\
\hline Halaman Login & 12 & 0 \\
\hline Halaman Data Pegawai & 12 & 0 \\
\hline Halaman Data Lembur & 12 & 0 \\
\hline Halaman Data Lembur Pegawai & 12 & 0 \\
\hline Halaman Laporan & 12 & 0 \\
\hline Total Jawaban & 60 & 0 \\
\hline
\end{tabular}

Berdasarkan hasil rekapitulasi 5 kriteria pengujian yang telah dilakukan didapatkan hasil jumlah jawaban dari responden yaitu mempunyai nilai $100 \%$ sesuai dengan pengujian fungsionalitas sistem menggunakan blackbox testing.

Hasil perbandingan analisis PIECES yang digunakan dari sistem yang telah berjalan dengan sistem yang telah dibuat adalah

Tabel 3. Hasil Perbandingan Analisis PIECES

\begin{tabular}{|l|l|l|}
\hline \multicolumn{1}{|c|}{ Analisis } & \multicolumn{1}{|c|}{ Sistem Lama } & \multicolumn{1}{c|}{ Sistem Baru } \\
\hline Performance & $\begin{array}{l}\text { Kinerja sistem yang } \\
\text { dilakukan secara excel } \\
\text { membutuhkan wakt yang } \\
\text { cukup lama untuk proses } \\
\text { perhitungan dan } \\
\text { pelaporannya. }\end{array}$ & $\begin{array}{l}\text { Kinerja sistem baru lebih } \\
\text { cepat untuk proses pelaporan } \\
\text { dan perhitungannya dengan } \\
\text { menggunakan sistem yang } \\
\text { terkomputerisasi dengan } \\
\text { bahasa pemograman C\# dan } \\
\text { firebase database serta } \\
\text { proses perhitungannya. }\end{array}$ \\
\hline Information & $\begin{array}{l}\text { Penyimpanan data masih } \\
\text { menggunakan flashdisk atau } \\
\text { hardisk sehingga banyak data } \\
\text { ganda (redundancy). }\end{array}$ & $\begin{array}{l}\text { Penyimpanan data } \\
\text { menggunakan basis data } \\
\text { sehingga mengurangi data } \\
\text { ganda karena data sudah di } \\
\text { integritas dalam satu } \\
\text { database. }\end{array}$ \\
\hline Economy & $\begin{array}{l}\text { biaya upah lembur yang } \\
\text { dikeluarkan sudah akurat. }\end{array}$ & $\begin{array}{l}\text { Biaya upah lembur yang } \\
\text { dikeluarkan lebih akurat. }\end{array}$ \\
\hline
\end{tabular}




\begin{tabular}{|c|c|c|}
\hline Control & $\begin{array}{l}\text { - Kurang adanya keamanan } \\
\text { data karena data tersimpan di } \\
\text { beberapa tempat. } \\
\text { - kurang adanya kontrol hasil } \\
\text { pekerjaan antara Staff dan } \\
\text { Supervisor HRD }\end{array}$ & $\begin{array}{l}\text { - Data disimpan dalam satu } \\
\text { database yang dilengkapi } \\
\text { dengan user dan password } \\
\text { sehingga orang lain tidak } \\
\text { bisa membuka data } \\
\text { tersebut. } \\
\text { - Sistem dilengkapi dengan } \\
\text { validasi sebelum laporan } \\
\text { dicetak sehingga laporan } \\
\text { lebih akurat kebenaranya. }\end{array}$ \\
\hline Efficiency & $\begin{array}{l}\text { Rekapitulasi yang masih } \\
\text { dilakukan secara spreadsheet } \\
\text { menyebabkan terjadinya } \\
\text { kesalahan dalam } \\
\text { memindahkan data dan } \\
\text { memakan waktu yang cukup } \\
\text { lama. }\end{array}$ & $\begin{array}{l}\text { Sistem baru memudahkan } \\
\text { untuk rekapitulasi karena } \\
\text { sudah dilakukan secara } \\
\text { otomatis oleh program. }\end{array}$ \\
\hline Service & $\begin{array}{l}\text { Proses pelayanan terhadap } \\
\text { perhitungan upah lembur } \\
\text { membutuhkan waktu apabila } \\
\text { terjadi kesalahan hitung. }\end{array}$ & $\begin{array}{l}\text { Pelayanan untuk perhitungan } \\
\text { upah lembur akan lebih cepat } \\
\text { karena sudah dilakukan } \\
\text { secara terkomputerisasi. }\end{array}$ \\
\hline
\end{tabular}

\section{KESIMPULAN}

Berdasarkan hasil penelitian yang telah dilakukan dalam perancangan sistem informasi akuntansi upah lembur karyawan menggunakan extreme programming sistem yang dihasilkan dapat membantu pihak PT Sugar Labinta dalam melakukan pengelolaan data lembur karyawan karena dapat mengatasi kesalahan dalam perhitungan upah lembur, sistem yang dibuat dengan metode pengembangan extreme programming juga lebih efektif dalam pengerjaan karena dapat menghasilkan aplikasi dengan tingkat efisiensi kinerja yaitu 75\% dari waktu target yang telah direncanakan, serta sistem informasi akuntansi yang dihasilkan dalam pembuatan laporan jurnal pengeluaran kas dapat membantu PT Sugar Labinta dalam mengelola pengeluaran kas.

\section{SARAN}

Saran yang dapat diberikan untuk pengembangan sistem baru yaitu dapat diintegrasikan dengan sistem penggajian, dan sistem informasi akuntansi pengeluaran kas untuk penggajian karyawan.

\section{DAFTAR PUSTAKA}

[1] H. Sulistiani, S. Setiawansyah, and D. Darwis, "Penerapan Metode Agile untuk Pengembangan Online Analytical Processing (OLAP) pada Data Penjualan (Studi Kasus: CV Adilia Lestari)," Jurnal CoreIT: Jurnal Hasil Penelitian Ilmu Komputer dan Teknologi Informasi, vol. 6, no. 1, pp. 50-56, 2020. 
[2] H. Sulistiani, R. Triana, and N. Neneng, "Sistem Informasi Akuntansi Pengelolaan Piutang Usaha untuk Menyajikan Pernyataan Piutang (Open Item Statement) Pada PT Chandra Putra Globalindo," Jurnal Tekno Kompak, vol. 12, no. 2, pp. 34-38, 2018.

[3] A. S. Rafika, E. Febriyanto, and E. Safriyati, "Perancangan Modul Trainer Interface Mikrokontroler Berbasis ESP32 Sebagai Media Pembelajaran Pada Mata Kuliah Embedded System," Technomedia Journal, vol. 5, no. 1 Agustus, pp. 118-131, 2020.

[4] S. D. Riskiono and U. Reginal, "Sistem Informasi Pelayanan Jasa Tour Dan Travel Berbasis Web (Studi Kasus Smart Tour)," Jurnal Informasi dan Komputer, vol. 6, no. 2, pp. 51-62, 2018.

[5] D. A. Megawaty, "SISTEM MONITORING KEGIATAN AKADEMIK SISWA MENGGUNAKAN WEBSITE,” Jurnal Tekno Kompak, vol. 14, no. 2, pp. 98-101, 2020.

[6] R. Rosyid and M. A. W. Prasetyo, "Robot Peraga 12 Gerakan Pengaturan Lalu Lintas Berbasis Arduino Mega 2560," Technomedia Journal, vol. 5, no. 2, pp. 193-205, 2021.

[7] B. D. Wicaksono and S. Anggraeni, "Perancangan Website Sistem Informasi Transaksi Tagihan Layanan Purna Jual Properti Pada Pollux Properti Indonesia," TMJ (Technomedia Journal) Vol. 5 No. 2 Februari 2021, p. 132, 2021.

[8] N. Cholisoh, J. Junaidi, and I. S. Sari, "Rancangan Sistem Penginputan Judul Online KKP, TA/SKRIPSI Berbasis Laravel Pada Universitas Raharja," Technomedia Journal, vol. 5, no. 2, pp. 248-258, 2021.

[9] S. Rahayu, A. Setiadi, and A. Muryanto, "Perancangan Sistem Pendaftaran Siswa Baru Secara Online Pada SMK Miftahul Jannah Cikupa," Technomedia Journal, vol. 5, no. 2, pp. 235-247, 2021.

[10] L. Sunarya, A. D. Purbayani, and N. Handayani, "Media Video Promosi Pada Roofpark Cafe \& Restaurant Pucak Bogor Jawa Barat," TMJ (Technomedia Journal) Vol. 5 No. 2 Februari 2021, p. 220, 2021.

[11] L. Sunarya, B. Abdurachman, and P. R. Ningsih, "Video Profile Balai Latihan Kerja Pada Dinas Ketenagakerjaan Kota Tangerang," Technomedia Journal, vol. 5, no. 2, pp. 206-219, 2021.

[12] Z. Fauziah, H. Latifah, X. Omar, A. Khoirunisa, and S. Millah, "Application of Blockchain Technology in Smart Contracts: A Systematic Literature Review," Aptisi Transactions on Technopreneurship (ATT), vol. 2, no. 2, pp. 160-166, 2020.

[13] I. Muhamad, W. Hidayat, and I. Handayani, "Perancangan Sistem Informasi Persediaan Barang Pada PT. Pacific Paint Menggunakan PHP dan MySQL," Technomedia Journal, vol. 5, no. 2, pp. 182-192, 2021.

[14] L. Munaroh, Y. Amrozi, and R. A. Nurdian, "Pengukuran Risiko Keamanan Aset TI Menggunakan Metode FMEA dan Standar ISO/IEC 27001: 2013," Technomedia Journal, vol. 5, no. 2, pp. 167-181, 2021.

[15] A. Roihan, N. Rahayu, and D. S. Aji, "Perancangan Sistem Kehadiran Face Recognition Menggunakan Mikrokomputer Berbasis Internet of Things," Technomedia Journal, vol. 5, no. 2, pp. 155-166, 2021.

[16] A. Maharani, S. Aninda, and S. Millah, "Pembuatan Kartu Ujian Online Sebagai Pengabdian Perguruan Tinggi," ADI Pengabdian Kepada Masyarakat, vol. 1, no. 2, pp. 8-14, 2021.

[17] D. Cahyadi, A. Faturahman, H. Haryani, and E. Dolan, "BCS: Blockchain Smart Curriculum System for Verification Student Accreditation," International Journal of Cyber and IT Service Management, vol. 1, no. 1, pp. 65-83, 2021. 
[18] A. Setiadi, I. Handayani, and F. Fadilah, "Perancangan Aplikasi Fit Your Weight Untuk Menghitung Berat Badan Ideal Berbasis Android," Technomedia Journal, vol. 5, no. 2, pp. 144-154, 2021.

[19] E. Febriyanto, T. Triyono, N. Rahayu, and R. Nurbaiti, "QRcode Verifikasi Sertifikat Sebagai Bukti Keabsahan Dokumen dalam Bidang Pendidikan," Technomedia Journal, vol. 5, no. 1 Agustus, pp. 96-105, 2020.

[20] I. Handayani, G. Maulani, E. Noviandri, and H. W. Ningsih, "Optimalisasi Sistem Pengelolaan E-Journal Berbasis Open Journal System (OJS) Menggunakan Framework CSS Bootstrap Pada Instansi dan Asosiasi," Technomedia Journal, vol. 5, no. 1 Agustus, pp. 106-117, 2020. 